'Roneod' sheets bound in paper covers (London : Institute of Industrial Administration, 1933. 5s.). They are none the worse for this, and two of them deal in an effective manner with difficult problems of distribution, and another is on research in industry, by Mr. A. P. M. Fleming.

IN few branches of social study, however, is there a greater tendency to discursiveness and mere talk than in these various divisions of industrial administration, especially in salesmanship and advertising; and in fewer still is there a greater misuse of the term 'science'. In the papers here published it must be admitted that this tendency is little in evidence. They are indeed bright, brief and stimulating. The discursive tendency is perhaps exhibited most in the first paper on personal and impersonal management, by $\mathrm{H}$. N. Munro, although his theme, so far as it can be definitely apprehended, seems sound enough. The next two papers, on distribution, are well worth reading and serious reflection, not only because this subject is one of the most important and difficult in the present age, but also because the authors strongly condemn that 'production complex' which is still too much in evidence in industrial management. One of them, based largely on personal experience, has an air of convincing reality and logic which is very attractive. It is scarcely necessary to say that Mr. Fleming's paper on research is characterised by his usual methodical and orderly presentation, and overwhelming arguments in support of far-sighted research policies and carefully thought-out research programmes. Other papers deal with finance and secretarial duties.

\section{Flood and Erosion Control}

Among the various expedients put forward for dealing with the problem of unemployment in the United States, one of considerable interest from a scientific point of view is that of Dr. L. E. Freudenthal, chairman of the Institute of Irrigation Agriculture, American Farm Bureau Federation, Las Cruces, N.M. In an address to the South-Western Division of the American Association for the Advancement of Science, which appears in Science of November 17,1933 , he points out that flood and erosion control are matters of national importance in America in that they are beyond the capacities of individual States to deal with. He instances the huge sums of money which have been beneficially expended on water supply, irrigation, water power and waterway undertakings and the equally enormous losses of life and property due to floods and erosion. The Mississippi flood of 1927, which inundated 18,000 square miles, drove 750,000 persons from their homes, did some $300,000,000$ dollars worth of damage and took 246 lives, is, he states, an example of what is happening annually on a smaller scale in nearly every State. For the last twenty years, flood damage in South Carolina and Tennessee has averaged nearly one million dollars per annum.

THE attendant erosion of fertile lands is stated by Dr. Freudenthal to be a national menace and he quotes a report of the U.S. Bureau of Soils to the effect that not less than 126 billion pounds of plant food material is removed from the fields and pastures of the United States every year, the value of the plant food elements in the waste being $2 \frac{1}{2}$ billion dollars annually. Erosion, adds Dr. Freudenthal, has been the principal cause for abandoning millions of acres of cleared land, and he goes on to suggest various directions in which Government assistance might be rendered in the matter of flood control measures with the object of providing relief for unemployment, including stream regulation, tree and brush planting, contour furrowing, protective fencing and seeding. $\mathrm{He}$ believes that flood and erosion control work are ideally suited for unemployment relief, not only for the reasonably effective results which could be obtained, but also because of the possible excellent effect upon the unemployed themselves.

\section{Darwin's Parish}

Sir Buckston Brown's generous gift to the British Association, in trust as a national possession, of Down House, Charles Darwin's home for forty years, and his further benefaction of the Research Farm of the Royal College of Surgeons at Downe, have revived the association with science of a secluded Kentish village which has retained much of its rural character, although within twelve miles of Charing Cross. It is sometimes forgotten that Downe was the residence of the Lubbocks and that it was here that John Lubbock, afterwards the first Lord Avebury, entered into the close and lifelong friendship with Darwin which exercised so great an influence on his scientific work. It is only reasonable to expect that those who visit Down House, now that it has become a place of scientific pilgrimage, should wish to know more of the history of its village. This need has been met in a little book ("A History of Darwin's Parish : Downe, Kent", Russell and Co., Southern Counties Ltd., Southampton, pp. viii +88 . 1s. 6d.) written by Dr. O.J.R. Howarth, secretary of the British Association, and Mrs. Howarth, with a foreword by Sir Arthur Keith, now also a resident of Downe. The parish history has nothing sensational to relate; but apart from the association with Darwin, it is interesting as a record of the life of a typical secluded English village-a life, which as the authors allow us to see by their skilful selection from humdrum records, was not without its humours and its tragedies. The evidence, which, so far as written documents are concerned, begins about A.D. 1100 , is fragmentary at the best; but the authors have made the most of their material and have produced a really informative and in. teresting account of the parish.

\section{Psychology in Germany}

The German Psychological Association's proceedings at its thirteenth congress, held at Leipzig on October 15-19, are reviewed in a thoughtful article, "Psychology under Hitler" by Goodwin Watson of Columbia University, in School and Society of 
December 2. In that assembly of more than six hundred, Jewish members of the Association, among whom are many who have been leaders of psychological thought, were conspicuous by their absenceand an opening address emphasised the demand for a psychology which expresses the genuine German spirit. Gestalt concepts were much in evidence and underlying all discussion was the assumption that parts are influenced by their membership character in larger wholes. It seems clear that "German psychology is developing a special concern for the type of Gestalt which is not limited to the perceptual field, but gives us the essential way of life of a whole personality". Of great practical significance was the address of Poppelreuter on political psychology. This directs attention to an increasing preoccupation with character and life as against intellect and theories and to the change of attitude brought about by the Hitler revolution, a change from an attitude of helplessness to one of determination to create, from disunity in economic ideas, political programmes, morality and world views to a sense of a common purpose. In the new whole of German culture, psychology no less than the other sciences must contribute to the realisation of the common purpose. "American psychologists," says Dr. Watson, "surveying the scene as spectators, may well wonder how long they can retain their own very considerable isolation from the major tasks of our generation." Coming as it does from the most influential focus of psychological doctrine in the United States, the comment is not without a certain piquancy.

\section{History of the Parsons Steam Turbine}

THE first issues for 1934 of the Engineer contain two instalments of a series of articles to be devoted to the development of the Parsons steam turbine. It is just fifty years since Sir Charles Parsons took out his patents for improvements in electric generators and improvements in rotary motors actuated by elastic fluid pressure, and constructed his first turbogenerator. This machine developed about $7.5 \mathrm{kw}$. To-day single turbo-generators of $100,000 \mathrm{kw}$. capacity are in use, and the present estimated value

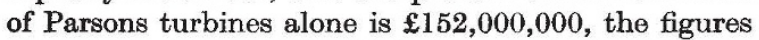
for marine and land turbines being $£ 92,000,000$ and $\mathfrak{1 6 0 , 0 0 0 , 0 0 0}$ respectively. Nothing to equal that rapid extension of value and dimensions has ever happened before. The publication of the series of articles will take many weeks and will appropriately mark the jubilee of this great invention. The first article contains a detailed description of the original turbo-generator, while the second, after referring to the early development of the parallel-flow turbines, deals with the radial-flow turbines of 1889-91.

\section{Automatic Voltage Control of Electrical Systems}

THe problems which arise in connexion with maintaining the voltage of supply constant in electrical distributing systems have been closely studied by electrical engineers during recent years. The per- missible variation allowed by the regulations is plus or minus four per cent of the 'declared' voltage, but the average regulation is much closer; the houses near the supply station at times of maximum load are supplied at a voltage above the declared pressure and the few near the ends of the distributing mains at a voltage below the normal. The lamps near the supply station therefore give a better light and have a shorter life than the distant lamps. In a paper read by W. Kidd and J. L. Carr to the Institution of Electrical Engineers on December 7, methods of automatic voltage regulation and switch control were described. The city of Manchester is the first area to have complete automatic voltage regulation and it also has supervisory control for its main sub. stations. By a careful application of automatically controlled regulators it is shown that the voltage on distribution networks can easily be maintained within the permissible limits. Manual control of voltage is never quite satisfactory and necessitates the uneconomic employment of additional labour. The installation of the regulating equipment gives better service to the public and removes a possible cause of complaint. It has to be remembered that a rise or fall in the voltage of one per cent increases or diminishes the light emitted by the lamp by about three per cent. Several diagrams are given showing methods of adapting existing transformers by means of automatically controlled tap-changing devices so that the voltage of supply can be kept constant at all loads.

\section{Organisation of a Social Centre}

IN a recently issued publication entitled "The Centre" (London: P. S. King and Son, Ltd. 3d.) various problems confronting the organisers of social centres for the unemployed are discussed by five contributors, who have had experience in the running of such centres. Special emphasis is laid on the importance of not losing sight of the individual in the mass, and of adapting the facilities provided to the needs of the individual. To prevent employables from becoming unemployable, though most desirable, is but a small part of a centre's activity. The way social centres can help best is to aid the individual to discover new powers, since this is the key to re-creation and progress. One person may need opportunities for thinking (study, reading, talks or discussions) ; another may wish to make something ; another may prefer some form of amusement (a game, dancing, gymnastics); others again may want advice as to cooking food, mending boots, making clothes or keeping well. It is no part of the purpose of a centre to compete with or undercut existing employment. It is conceivable that certain articles such as handwoven scarves might find a ready market, but the repeated manufacture of products of the same kind is not the aim of a social centre. The work there should be undertaken for the sake of the effect which the making has upon the maker. Its purpose is to perfect the individuals and this will not be obtained by encouraging them to do tho same thing over and over again. 